KAWISTARA

VOLUME 3

No. 2, 17 Agustus 2013

Halaman 117-226

\title{
PRAKTIK TANGGUNG JAWAB SOSIAL PERUSAHAAN PT. BAKRIE SUMATRA PLANTATIONS(TBK.) UNIT JAMBI
}

\author{
Suwandi \\ PT. Bakrie Sumatra Plantations, Tbk., Provinsi Jambi \\ Email:suwandi@bakriesumatera.com \\ Yeremias T. Keban \\ Fakultas Ilmu Sosial dan Ilmu Politik Universitas Gadjah Mada \\ Edi Martono \\ Fakultas Pertanian Universitas Gadjah Mada
}

\begin{abstract}
Companies all over the world have implemented corporate social responsibility. This research is aimed toanalyze factors affecting CSR practice by Bakrie SumatraPlantations Unit Jambi, a palm oil plantation company. The CSR practice was hypothesized to be influenced by government regulation and corporate strategy. The primary data was collected through survey, interviews, focused group discussion, and direct observation in the field. Meanwhile, the secondary data was gathered from various documents. The data was analyzed by using quantitative and qualitative approaches.The result shows that the government regulation CSR has no impact on the CSR practice. On the reverse, the corporate commitment and strategy were the decisive factors in the successful of CSR practice. This research also found that the CSR practice has contributedto the improvement of people's economic and social conditions. The prominent weakness is that the CSR policies and strategies were top-down and the participation of local people were limited. The other empirical finding is that the nucleus-plasma partnership was able to implement the basic principles of CSR which were prevailing generally in different sector of businesses.
\end{abstract}

Keywords: Government Policy, Corporate Strategy, CSR Practice, Nucleus-Plasma Partnership, Palm Oil.

\footnotetext{
ABSTRAK

Perusahaan di seluruh dunia telah menerapakan tanggung jawab perusahaan. Penelitian ini bertujuan untuk menganalisis faktor yang mempengaruhi praktik CSR oleh Bakrie Sumatra Plantations Satuan Jambi, yaitu sebuah perusahaan perkebunan kelapa sawit. Praktik CSR adalah hipotesis dipengaruhi oleh peraturan pemerintah dan strategi perusahaan. Data primer dikumpulkan melalui survey, wawancara, diskusi kelompok yang terfokus, dan observasi langsung di lapangan. Sementara itu, data sekunder dikumpulkan dari berbagai dokumen.Data dianalisis menggunakan pendekatan kuantitatif dan kualitatif.Hasilnya menunjukkan bahwa peraturan pemerintah tentang CSR, ternyata tidak berdampak pada praktik CSR. Sebaliknya, komitmen dan strategi perusahaan adalah faktor yang menentukan dalam keberhasilan praktik CSR. Penelitian ini juga menemukan bahwa praktik CSR telah memberikan kontribusi terhadap perbaikan kondisi ekonomi dan sosial masyarakat.Kelemahan yang
} 
menonjol adalah kebijakan dan strategi CSR yang naik turun dan partisipasi masyarakat lokal yang terbatas. Temuan empiris lain bahwa kemitraan inti plasma mampu menerapkan prinsip-prinsip dasar CSR yang berlaku umum di sektor bisnis yang berbeda.

Kata Kunci: Kebijakan Pemerintah, Strategi Perusahaan, Praktik CSR, Kemitraan Inti Plasma, Kelapa Sawit.

\section{PENGANTAR}

Corporate social responsibility (CSR) telah menjadi alat harmonisasi sosial yang efektif dengan menyeimbangkan kepentinganmasyarakat dan bisnis perusahaan. Dimensi CSR yang mencakup ekonomi, sosial, hukum, etika, lingkungan, dan lain-lain telah dikaji oleh berbagai peneliti.Perusahaan-perusahaan komputer berskala besar selama 20 tahun terakhir telah menciptakan industri yang memengaruhi semua orang, mengubah kehidupan dan bisnis, menghasilkan miliaran dolar, dan menciptakan ribuan kesempatan kerja.Peran CSR adalah meminimalkan konflik di antara perusahaan dengan masyarakat (Heal, 2005: 387 dan 394). Etika bisnis, evaluasi moral dari perilaku perusahaan difokuskan pada dampak dari perusahaan terhadap hakhak dan legitimasi dari para pemangku kepentingannya (Ven dan Jeurissen, 2005: 229).

Quevedo-Puente, Fuente-Sabaté, dan Delgado-García (2007: 60) mengungkapkan kedekatan konseptual di antara corporate social performance dengan reputasi perusahaan. CSR bukanlah filantropi atau belas kasihan(Hopkins, 2007: 113). Hasil survei di Eropa, Amerika Utara, dan Asia yang dilakukan Welford menunjukkan bahwa perusahaan-perusahaan di Asia cukup maju dalam menerapkan CSR. Di Indonesia, konsep CSR mulai diterapkan pada tahun 1990-an, tetapibaru dipraktikkan secara formal sejak berlakunya Undang-Undang Nomor 40 Tahun 2007 tentang Perseroan Terbatas(Welford, 2004: 35).

Salah satu perusahaan yang berkontribusi mendukung pelaksanaan tanggung jawab sosial adalah BSP Unit Jambi. Model CSR dijalankan sesuai dengan kebutuhan masyarakat dan memperhatikan kebijakan pemerintah. Kemitraan yang sinergis di antara BSP Unit Jambi dan para petani selaku pemangku kepentingan diharapkan dapat meningkatkan kesejahteraan para petani kelapa sawit. Wood dan Jones (1995) menemukan bahwa CSR berpengaruh positif terhadap kinerja perusahaan dan kesejahteraan masyarakat. Peneliti lain menyimpulkan bahwa CSR bersifat netral (Preston dan Bannon, 1997; McWilliams dan Siegel, 2000). Hilman dan Keim (2001), bahkan menegaskan bahwa implementasi CSR justru membawa kerugian.

Morimoto, Ash, dan Hope (2004) menganalisis pengembangan sistem audit CSR yang didasarkan pada analisis literatur dan wawancara dengan pemangku kepentingan. Kerangka kerja dibangun menggunakan Grounded Theory. Morimoto, Ash, dan Hope (2004: 1) mengemukakan bahwa tema lingkungan dan tanggung jawab sosial telah mendapatkan perhatian yang semakin besar. Peneliti lain, yaitu Welford (2004), menganalisis praktik CSR di 15 negara di Eropa, Amerika Utara, dan Asia. Survei dilakukan untuk menilai 20 elemen CSR yang disusun berdasarkan konvensi internasional, kode etik, dan praktik terbaik industri. Di samping itu, kebijakan di bidang pekerja anak peningkatannya dititikberatkan pada etika, penyuapan, dan korupsi (Welford, 2004: 33). Perkembangan praktik CSR di Asia, khususnya di Jepang, tidak kalah dari perusahaan-perusahaan di Eropa dan Amerika Utara. Temuan lainnya adalah terdapat hubungan antara pengembangan CSR dengan perekonomian di berbagai negara.

Heal (2005: 387) mendefinisikan CSR sebagai suatu program aksi untuk mengurangi biaya eksternal atau menghindari konflik. CSR dapat memperbaiki profit dan melindungi reputasi perusahaan. Menurut Ven dan Jeurissen (2005: 299), kekuatan kompetisi yang berbeda menghasilkan legitimasi moral yang berbeda dalam perilaku perusahaan. 
Meskipun etika bisnis menyatakan bahwa perusahaan harus melakukan investasi tanggung jawab sosial, tetapi teori normatif mengenai pengaruh kondisi persaingan terhadap tanggung jawab sosial perusahaan belum berkembang.

Reputasi perusahaan menjadi aspek penting dan terkait dengan kinerja tanggung jawab sosial. Substansi ini diteliti oleh Quevedo-Puente, Fuente-Sabaté, dan Delgado-García (2007). Kedua konsep dihubungkan oleh legitimasi perusahaan, yaitu proses menerjemahkan kinerja di masa lalu menjadi suatu ekspektasi di masa datang. Kinerja sosial perusahaan yang baik mengonsolidasikan reputasi dari waktu ke waktu. Nurn dan Tan (2010) telah mengembangkan suatu kerangka kerja konseptual yang menggambarkan manfaat dari CSR. Praktik CSR yang baik menurut Nurn dan Tan (2010: 362) menghasilkan manfaat yang tidak tampak, seperti reputasi, komitmen, dan pembelajaran, serta manfaat yang tampak yang meliputi pengurangan tingkat perputaran dan biaya operasional serta meningkatnya efisiensi. Akan tetapi, masih perlu dilakukan penelitian mengenai aspek kepercayaan dan motivasi dalam menjalankan CSR. Sentimen karyawan terhadap CSR masih jarang dilakukan (Alidkk., 2010:2.796). Padahal, CSR dapat mendorong komitmen karyawan terhadap organisasi sehingga memperbaiki kinerja. Praktik CSR selama ini lebih menekankan penyediaan sumber daya bagi peningkatan kesejahteraan masyarakat. Peneliti pada umumnya memberikan rekomendasi kepada perusahaan untuk memperhatikan jumlah dana CSR sebagai investasi dan bukan pengeluaran. Perusahaan menggunakan CSR untuk memperkuat hubungannya dengan pemangku kepentingan, menjamin berkurangnya konflik, dan meningkatkan loyalitas.

Penelitian ini diawali dengan evaluasi terhadap kesesuaian praktik CSR oleh BSP Unit Jambi dengan regulasi pemerintah. Selanjutnya, dilakukan analisis terhadap strategi perusahaan dalam melaksanakan
CSR, terutama Kemitraan Inti-Plasma. Kinerja CSR diukur dari manfaat yang dihasilkan bagi peningkatan kesejahteraan masyarakat. Meskipun kelapa sawit telah menjadi salah satu komoditas perkebunan terpenting di Indonesia, tetapi penelitian mengenai penerapan CSR di perusahaan perkebunan kelapa sawit masih langka. Penelitian ini melakukan evaluasi terhadap praktik CSR oleh BSP Unit Jambi dengan fokus pada Kemitraan Inti-Plasma. Data primer bersumber dari petani plasma kelapa sawit dan karyawan BSP Unit Jambi. Pengumpulan data primer dilakukan melalui survei dengan menggunakan kuesioner, diskusi kelompok terfokus (FGD), observasi langsung, dan wawancara. Penentuan responden survei dilakukan melalui sampling kuota, sedangkan responden FGD, dan wawancara ditentukan melalui purposive sampling.

Survei dilakukan di12 desa di Kecamatan Tungkal Ulu, Kabupaten Tanjung Jabung Barat, Provinsi Jambi. Secara keseluruhan, terdapat 4.564 orang petani plasma kelapa sawit.Pada populasi penelitian diambil sampel 456 petani plasma atau 10 persen dari populasi, sedangkan untuk karyawan BSP Unit Jambi ditetapkan sampel sebanyak 16 orang.

Data dianalisis menggunakan pendekatan kuantitatif dan kualitatif. Analisis kuantitatif meliputi uji validitas, uji reliabilitas, statistik deskriptif, dan test for equality of means between series. Sedangkan analisis data kualitatif diarahkan pada conversation analysis dan content analysis. Conversation analysis dilakukan dengan menggunakan hasil FGD dan wawancara dengan para pemangku kepentingan. Sedangkan content analysis ditempuh dengan melakukan coding. Pemrosesan data kualitatif dilakukan menggunakan triangulasi jawaban.

\section{PEMBAHASAN \\ Peran Kebijakan Pemerintah}

Kebijakan pemerintah yang terkait dengan praktik CSR masih bersifat normatif. Tidak dijumpai kebijakan yang sangat 
spesifik mengatur praktik CSR, sehingga dampak kebijakan pemerintah bersifat tidak langsung. Akan tetapi, BSP Unit Jambi tidak kesulitan dalam merespons kebijakan pemerintah karena semua kegiatan CSR mendukung kebijakan pemerintah. Pemerintah bersikap pasif dan memberikan ruang yang fleksibel bagi perusahaan dalam menjalankan CSR. BSP Unit Jambi melakukan interpretasi sendiri terhadap kesesuaian mekanisme CSR yang dijalankan dengan kebijakan pemerintah. BSP Unit Jambi menjalankan kegiatannya di bidang perkebunan melalui Kemitraan Inti-Plasma.

Semakin maju suatu negara, semakin besar pula kemungkinan perusahaanperusahaan di negara tersebut menjalankan CSR karena tersedia regulasi. Jerman dan Inggris menjadi pemimpin di Eropa, Jepang, Korea Selatan di Asia, dan Meksiko di Amerika Utara. Kebijakan CSR mudah dijumpai di negara-negara yang memiliki tradisi demokrasi, seperti Jerman, Norwegia, dan Kanada (Welford, 2004: 52). Praktik CSR sering dikaitkan dengan penanggulangan berbagai persoalan sosial dan sekaligus merupakan salah satu instrumen dunia usaha dalam mendorong kinerja dan menjaga reputasi perusahaan. Schafer (2005: 107) mengingatkan bahwa para pemangku kepentingan dewasa ini telah semakin sering mempertanyakan kinerja ekonomi, lingkungan, dan sosial dari perusahaan. Untuk itu, strategi yang dijalankan pelaku bisnis sudah sewajarnya mengikuti dan menyesuaikan dengan peraturan perundangundangan yang berlaku.

Hasil wawancara menunjukkan terdapat responden yang mendukung peran pemerintah, tetapi lebih banyak yang mengkritik kontribusi pemerintah dalam mendorong praktik CSR oleh perusahaan. Kontribusi pemerintah dikatakan kurang memadai dan tidak tepat sasaran. Responden yang mendukung menyatakan bahwa peran pemerintah dalam mendorong pelaksanaan CSR di Indonesia sangat kuat, yaitu dengan dikeluarkannya undang-undang tentang kewajiban CSR bagi perusahaan. Persoalan yang muncul adalah pengendalian dan pengawasan terhadap pelaksanaannya sangat lemah. Aparat pemerintah saat ini masih bersifat pasif dalam membangun komunikasi dengan perusahaan mengenai pelaksanaan CSR. Peran pemerintah sudah cukup baik melalui pemberian penghargaan kepada perusahaan yang melaksanakan CSR dengan baik. Akan tetapi, lembaga-lembaga pemerintah juga berlomba-lomba mendekati perusahaan untuk bekerjasama dalam melaksanakan CSR tanpa koordinasi.

\section{Peran Strategi Perusahaan}

Komitmen perusahaan menjadi kata kunci bagi kinerja CSR. Responden karyawan yang disurvei mengemukakan beragam kelemahan atau kekurangan dalam pelaksanaan CSR oleh BSP Unit Jambi sebagai berikut: (1) masih terbatasnya anggaran; (2) pelaksanaan CSR yang kurang atau belum merata di kalangan masyarakat; (3) bidang CSR masih terbatas; (4) pelaksanaan CSR belum terjadwal dengan baik; (5) tidak adanya tindak lanjut atau program CSR cederung tidak berkelanjutan; (6) sosialisasi belum dilakukan secara kontinu; dan (7) belum adanya tim khusus untuk mengevaluasi pelaksanaan Program CSR.

Beragam kelemahan/kekurangan juga dikemukakan responden petani plasma, yaitu (1) perusahaan jarang melakukan komunikasi (tidak terbuka), sosialisasi, penyuluhan, diskusi, koordinasi, atau pendekatan lainnya mengenai hal-hal yang terkait dengan CSR kepada masyarakat; (2) pelaksanaan CSR tidak tepat sasaran dan lamban memenuhi permintaan masyarakat;(3) komunikasi di lapangan sangat terbatas;(4)Program CSR belum merata, sehingga belum menjangkau seluruh lapisan masyarakat; (5) Program CSR masih terbatas/minim dan tidak dilaksanakan secara kontinu; (6) bantuan CSR selama ini hanya ditujukan bagi orangorang tertentu dan tidak transparan; (7) pelaksanaan CSR tidak dilakukan dengan bermitra sejak awal bahwa pengambilan keputusan seringkali dilakukan sepihak oleh perusahaan dan tidak melibatkan petani 
plasma selaku mitra; (8) tidak sampainya bantuan CSR kepada penerima manfaat; (9) kurang diperhatikannya masukanmasukan dari masyarakat;(10) perusahaan kurang memperhatikan ketidak mampuan masyarakat; (11) kondisi masyarakat seringkali diseragamkan dan tidak terdapat upaya khusus untuk mengakomodasi perbedaan karakteristik masyarakat pada wilayah tertentu; serta (12) keluhan petani lebih banyak diabaikan karena penyampaian saran/kritik relatif terbatas.

Berbagai kelemahan tersebut, terdapat sejumlah responden menyatakan bahwa perhatian/kepedulian dan bantuan perusahaan kepada petani masih kurang. Selain itu, dijumpai pula responden yang berpendapat bahwa pelaksanaan CSR belum maksimal. Pendapat ini didukung oleh banyak responden petani plasma lainnya dalam berbagai bentuk pernyataan yang bersifat teknis, seperti kurangnya/atau tidak adanya pengangkutan Tandan Buah Segar (TBS) dari kebun ke Pabrik Kelapa Sawit (PKS), tidak adanya jaminan keamanan dalam pengangkutan TBS ke PKS, pembongkaran TBS di pabrik lambat, kurangnya perbaikan atau perawatan jalan (poros) dan goronggorong, kurangnya penyediaan pupuk, bibit unggul, dan penyuluhan perkebunan, tidak adanya penyuluhan mengenai hama/ penyakit yang menyerang tanaman kelapa sawit, kurangnya pembinaan terhadap petani plasma, tidak adanya transportasi untuk anak sekolah, serta kurangnya bantuan untuk sektor pendidikan.

Di samping kelemahan/kekurangan, menurut responden karyawan, pelaksanaan CSR mempunyai beberapa kekuatan/ kelebihan, seperti: (1) terjalinnya komunikasi dan keharmonisan di antara perusahaan dan petani plasma dan (2) sosialisasi antara lain mengenai peraturan lingkungan hidup yang disertai ajakan kepada masyarakat untuk menaatinya, sehingga kelestarian lingkungan dapat terjaga. Kekuatan atau kelebihan dari pelaksanaan CSR oleh BSP Unit Jambi sangat bervariasi dalam pandangan responden petani plasma yang meliputi: (1) perbaikan pendapatan/penghasilan dan kesejahteraan; (2)memberantas kemiskinan; (3) membuka dan menambah lapangan kerja;(4) membantu pendidikan anak-anak petani plasma; (5) memperlancar transportasi setempat; (6) meningkatkan kondisi kesehatan masyarakat; (7) meningkatkan hubungan sosial dan memberikan manfaat karenabantuan diberikan secara langsung kepada masyarakat, tanpa prosedur yang berbelit-belit; (8) perusahaan secara terusmenerus memberikan bimbingan sejak awal, yaitu membantu pembuatan/pembukaan lahan kebun kelapa sawit hingga para petani plasma mampu melunasi hutangnya; (9) harga TBS yang dibeli perusahaan dari para petani plasma lebih tinggi dan konsisten dibandingkan apabila TBS yang dihasilkan dijual kepada para tengkulak; dan (10) petani plasma diberikan kesempatan untuk memiliki lahan yang dikelola dalam bentuk sertifikat hak milik.

Menurut para responden, Perlu dibentuk unit kerja khusus yang menangani masalah lingkungan menurut para responden. Selain itu, perusahaan harus lebih aktif dalam membina petani, antara lain dengan membentuk suatu forum diskusi untuk membahas berbagai persoalan yang terkait dengan CSR. Forum diskusi yang ada saat ini masih bersifat temporer atau insidentil, sehingga belum mampu menampung aspirasi petani plasma secara periodik dan komprehensif.

Pada tahun 2011, BSP merealisasikan dana investasi sosial sebesar Rp 4,2 miliar atau 81,51 persen dari total dana investasi sosial yang dicadangkan sebesar Rp 5,2 miliar. Untuk tahun 2012, pelaksanaan CSR lebih difokuskan pada bidang pendidikan, ekonomi, dan sosial dengan dana investasi sosial sebesar Rp 10-11 miliar. Dana ini akan disalurkan pada delapan bidang strategis, yaitu pendidikan, ekonomi, kesehatan, keagamaan, kepemudaan, lingkungan, infrastruktur, serta tanggap bencana dan donasi (Anonim, 2012: 23). Kemitraan IntiPlasma diarahkan untuk menghasilkan beragam manfaat bagi petani plasma 
maupun perusahaan. Strategi yang disusun mendorong terbentuknya kebersamaan yang dilandasi prinsip saling terbuka, percaya, membutuhkan, melengkapi, menyempurnakan, dan menguntungkan. Praktik CSR oleh BSP Unit Jambi melalui beberapa strategi implementasi yang meliputi sosialisasi, penyampaian informasi, partisipasi masyarakat, penilaian kebutuhan, penetapan sasaran, pemantauan, dan evaluasi.

Berdasarkan survei terhadap 16 karyawan BSP Unit Jambi diketahui bahwa perusahaan telah menyosialisasikan Program CSR dalam bentuk tatap muka dan melalui media cetak. Sejumlah 15 responden atau 93,75 persen menyatakan bahwa sosialisasi yang dilakukan telah cukup memadai. Jawaban ini berbeda dengan petani plasma yang masih merasakan kurangnya sosialisasi CSR. Seorang responden lainnya atau 6,25 persen sangat setuju.

Kelemahan/kekurangan sosialisasi yang diakui oleh para responden di antaranya bersumber dari hambatanhambatan pada budaya setempat. Selain itu, sosialisasi yang dilakukan tidak terjadwal atau belum terprogram dengan baik serta belum dilakukan secara merata. Penyebab utama kondisi ini menurut pandangan para responden adalah kurangnya dana yang disediakan untuk melakukan sosialisasi CSR kepada masyarakat dan belum adanya petugas yang secara khusus bertugas melakukan sosialisasi.

Sebaliknya, kekuatan atau kelebihan sosialisasi CSR adalah efektivitas dalam koordinasi dan komunikasi. Pendekatan persuasif juga diapresiasi masyarakat. Kekuatan atau kelebihan lainnya adalah sosialisasi yang dilakukan secara serentak dengan mengumpulkan masyarakat di dalam suatu forum, sehingga terjalin hubungan yang lebih baik. Kemampuan petugas yang mahir dan berpengalaman dikatakan pula sebagai kekuatan atau kelebihan dalam melakukan sosialisasi secara berkesinambungan, selain karakter masyarakat yang terbuka. Penyampaian informasi mengenai CSR, hampir seluruh responden menyatakan setuju bahwa informasi yang disampaikan kepada masyarakat telah cukup baik. Persepsi ini dikemukakan oleh 15 responden atau 93,75 persen dan hanya satu responden atau 6,25 persen yang menyatakan netral. Tidak dijumpai satupun responden karyawan BSP Unit Jambi yang menyatakan sangat setuju, tidak setuju, atau sangat tidak setuju.

Kelemahan atau kekurangan yang dijumpai dalam penyampaian informasi mengenai CSR adalah informasi yang terlambat atau tidak up-to-date. Di samping itu, informasi yang disampaikan kebanyakan tidak tertulis, sehingga seringkali tidak terekam dan terkesan tidak resmi. Terdapat pula responden yang mengungkapkan bahwa informasi yang disampaikan terkadang tidak tepat sasaran, kurangnya media yang digunakan, serta informasi belum merata.Pada segi kandungan informasi, dikeluhkan bahwa program yang diinformasikan kepada masyarakat belum detil atau transparan. Informasi seringkali hanya sampai kepada karyawan perusahaan dan belum menjangkau pihak luar atau seluruh lapisan masyarakat.

Adapun kekuatan atau kelebihan dalam cara penyampaian informasi mengenai CSR, adanya komunikasi di lapangan di antara petugas dengan masyarakat, meskipun frekuensinya belum sesuai harapan. Selain itu, ketersediaan Majalah Harmoni dan media internet dipandang sebagai kekuatan atau kelebihan dalam penyampaian informasi. Informasi yang disampaikan relatif cepat dan menarik perhatian, sehingga tingkat partisipasi masyarakat cukup baik. Kekuatan atau kelebihan lainnya, adanya sosialisasi kepada pihak luar secara berkesinambungan, sehingga mitra perusahaan dapat mengikuti perkembangan CSR dengan saksama. Pendekatan persuasif dalam menyampaikan informasi, tersedianya prasarana dan sarana, serta dukungan penuh dari manajemen merupakan kekuatan atau kelebihan dalam penyampaian informasi yang terungkap pula dari hasil survei.

Responden menyarankan perlunya pembuatan laporan CSR secara tertulis 
yang up-to-date dan dibentuknya forum stakeholder. Disarankan pula untuk melakukan studi banding sebagai upaya melakukan komparasi. Media yang lebih banyak tersedia merupakan usulan lainnya, misalnya dalam bentuk poster atau majalah dinding, sehingga petani plasma dapat mengikuti perkembangan CSR secara lebih intensif. Perluasan cakupan pendistribusian media cetak maupun elektronik merupakan hal yang juga perlu diperbaiki. Responden lainnya mengungkapkan perlunya sosialisasi secara kontinu kepada pihak luar dan informasi yang disampaikan harus lebih fokus. Di samping itu, disarankan membentuk wadah perwakilan petani yang dapat membantu menyampaikan informasi secara lebih jelas dan tepat waktu.

Sejumlah 15 responden atau 93,75 persen setuju bahwa partisipasi masyarakat telah cukup memadai dalam perencanaan dan pelaksanaan CSR. Hanya 1 responden atau 6,25 persen yang menyatakan netral. Tidak ditemukan satu respondenpun yang sangat tidak setuju, tidak setuju, atau sangat setuju.Cara yang ditempuh dalam melibatkan masyarakat pada perencanan dan pelaksanaan CSR diawali melalui pemetaan sosial dalam forum rembug desa. Petugas CSR berkomunikasi dengan masyarakat secara langsung untuk membahas beragam kebutuhan. Cara lain adalah melalui penyuluhan, sosialisasi, dan koordinasi dengan pemuka masyarakat setempat.

Beberapa responden lainnya mengemukakan bahwa keterlibatan masyarakat diakomodasi melalui survei lapangan untuk meminta, menanyakan, atau memantau informasi secara langsung dan menampung proposal yang diajukan oleh masyarakat. Di samping itu, perusahaan juga bekerjasama dengan pemerintah dan melaksanakan studi dampak sosial. Kesemuanya ditujukan untuk mengidentifikasi kebutuhan aktual masyarakat. Sekalipun berbagai upaya telah ditempuh, tetapi menurut para responden, terdapat berbagai kelemahan atau kekurangan dalam cara melibatkan masyarakat. Misalnya, pendataan tidak dilakukan dengan melibatkan lembaga lokal, sehingga akurasinya perlu dipertanyakan. Pembahasan mengenai dana CSR juga belum melibatkan semua elemen masyarakat, di samping terkesan kurang transparan karena tidakmendiskusikansemuaaspeksecararinci. Banyak kasus, jumlah pemuka masyarakat yang terlibat dalam pembahasan CSR sangat terbatas, sehingga perencanaan CSR belum dapat dikatakan partisipatif. Terdapat pula responden yang menyatakan bahwa proses yang dilalui terkadang agak subyektif. Responden lainnya mengungkapkan bahwa dana yang dibutuhkan oleh tenaga pelaksana di lapangan relatif terbatas, sehingga membatasi keperluan melakukan survei langsung ke lapangan.

Kekuatan atau kelebihan dalam cara melibatkan masyarakat, yaitu pelaksanaan Program CSR selama ini berdasarkan pada hasil diskusi dengan masyarakat. Selain itu, penyampaian informasi dipandang sudah baik atau memadai, sehingga bantuan CSR tepat pada sasaran. Pelaksanaan CSR juga dipandang transparan karena perencanaannya yang telah sesuai dengan kebutuhan dan aspirasi masyarakat. Bahkan menurut seorang responden, masukanmasukan dari masyarakat dijadikan sebagai pedoman. Kekuatan atau kelebihan lainnya adalah penggunaan sosialisasi dan diskusi sebagai media untuk menampung aspirasi masyarakat. Kondisi ini membuat CSR dipandang terencana dengan baik. Di samping itu, terdapat dukungan yang luas dari masyarakat maupun instansi pemerintah. Kekuatan atau kelebihan yang tidak kalah pentingnya bahwa penetapan sasaran CSR selalu dikoordinasikan dengan pengelola Koperasi Unit Desa (KUD) dan pemuka masyarakat.

Sebanyak 15 responden atau 93,75 persen setuju bahwa cara menilai kebutuhan dan menetapkan sasaran yang dilakukan oleh BSP Unit Jambi telah cukup baik atau memadai. Hanya 1(satu) responden atau 6,25 persen yang bersikap netral. Selain itu, tidak satupun responden yang memiliki persepsi sangat tidak setuju, tidak setuju, atau sangat setuju. 
Cara menilai kebutuhan dan menetapkan sasaran dipandang sudah cukup baik/memadai oleh sebagian besar responden dikarenakan telah dilakukan melalui komunikasi, pemetaan sosial, dan diskusi. Langkah-langkah ini sejalan dengan survei dan pengamatan langsung ke lapangan untuk menemui masyarakat di sekitar lokasi perusahaan. Diskusi dan koordinasi sering dilakukan dengan pemuka masyarakat untuk menyerap informasi mengenai kebutuhan aktual masyarakat.

Kelemahan/kekurangan dalam cara menilai kebutuhan dan menetapkan sasaran yang dikemukakan oleh para responden diawali dengan dana CSR yang terbatas. Keterbatasan dana menyebabkan tidak semua program dapat terpenuhi, sehingga terkesan pemberian bantuan belum tepat sasaran. Kelemahan atau kekurangan lainnya adalah kurangnya jumlah perwakilan masyarakat di dalam forum diskusi serta belum adanya jadwal tetap dalam penilaian kebutuhan dan penetapan sasaran penerima Program CSR.

Keberadaan perwakilan masyarakat yang terbatas menyebabkan proses penilaian kebutuhan dan penetapan sasaran CSR dikatakan subyektif. Hal ini seringkali ditempuh untuk memilih jenis-jenis kegiatan berdasarkan kebutuhan yang mendesak dan dapat diterima oleh seluruh masyarakat. Jenis-jenis kegiatan yang terus-menerus berubah juga dikeluhkan oleh responden, selain kurangnya tenaga lapangan. Keterbatasan petugas sering menyebabkan pengumpulan data menjadi tidak terperinci dan kurang akurat.

Para responden juga mengungkapkan kekuatan atau kelebihan dalam cara menilai kebutuhan dan menetapkan sasaran penerima manfaat CSR. Kondisi masyarakat di lokasi perusahaan yang sudah mapan merupakan salah satu kekuatan atau kelebihan. Selain itu, proses penilaian kebutuhan dan penetapan sasaran selama ini telah menjadi bagian dari kegiatan kelompok untuk membangun komunikasi yang lebih intensif di antara masyarakat dan perusahaan.Komitmen perusahaan yang kuat merupakan kekuatan atau kelebihan yang sangat mendasar. Komitmen dimaksud adalah dalam menjalankan hasil-hasil penilaian kebutuhan masyarakat dari bawah. Komitmen dapat pula dilihat dari intensitas turun ke lapangan untuk berdiskusi dengan masyarakat. Tatap muka di lokasi selama ini dilakukan melalui koordinasi dengan pihak KUD dan pemuka masyarakat.

Terdapat sejumlah hal yang perlu dilakukan untuk memperbaiki cara menilai kebutuhan dan menetapkan sasaran CSR. Pertama adalah perlunya dukungan dana yang memadai. Selanjutnya, perlu dibangun komunikasi dua arah yang lebih intensif. Komunikasi dapat dilakukan melalui diskusi di dalam forum stakeholder.

Sejumlah 15 responden atau 63,75 persen setuju bahwa cara evaluasi yang dilakukan oleh BSP Unit Jambi telah cukup baik/ memadai. Sedangkan seorang responden atau 6,25 persen memiliki persepsi netral. Dengan demikian, tidak satupun dari 16 responden yang sangat tidak setuju, tidak setuju, atau sangat setuju.

Cara evaluasi terhadap pelaksanaan CSR adalah dengan monitoring langsung ke lapangan, sehingga dapat berinteraksi dengan penerima manfaat. Hasil monitoring digunakan untuk mengevaluasi kegiatankegiatan yang telah dijalankan dan merencanakan tindak lanjut serta kegiatan pada tahun-tahun selanjutnya. Interaksi dengan penerima manfaat dilakukan dalam bentuk sosialisasi dan diskusi.

Beberapa kelemahan atau kekurangan bahwa cara yang dilakukan tidak dapat mengevaluasi Program CSR secara keseluruhan. Selain itu, temuan-temuan dari evaluasi belum banyak yang ditindaklanjuti. Evaluasi CSR belum terjadwal dengan baik atau rutin, di samping belum ada petugas atau tim khusus. Kelemahan atau kekurangan yang terakhir adalah bahwa evaluasi yang ditempuh selama ini belum melibatkan seluruh pihak. Sebanyak tiga responden tidak mengungkapkankelemahan ataukekurangan dari cara evaluasi, tetapi menyampaikan temuan-temuan evaluasi bahwa Program 
CSR tidak berjalan sepenuhnya. Di samping itu, pemberian bantuan masih belum tepat sasaran. Selanjutnya, Program CSR tidak memberikan alternatif atau menerima masukan, tetapi telah ditentukan sejak awal.

\section{Praktik CSR}

Pelaksanaan Program CSR sangat dipengaruhi oleh komitmen dan strategi perusahaan. Model CSR yang dipraktikkan BSP Unit Jambi pada dasarnya mengikuti model yang dikembangkan oleh BSP. Landasan pengambilan keputusan CSR di BSP hingga saat ini masih lebih didominasi dari atas. Sementara itu, informasi dari bawah juga dikumpulkan dan dijadikan bahan pertimbangan, tetapi memiliki daya tawar yang rendah. Kondisi ini menyebabkan model CSR yang dipraktikkan dapat dikategorikan sebagai model CSR yang lebih bersifat top-down dibandingkan bottom-up.

Skala, ruang lingkup, dan alokasi dana untuk CSR merupakan proporsi tertentu dari laba bersih. Semakin besar laba bersih yang dihasilkan oleh BSP, maka semakin besar pula skala pelaksanaan CSR, dan demikian pula sebaliknya. Selain itu, regulasi pemerintah di tingkat pusat maupun daerah juga menjadi pertimbangan.

Model CSR BSP, kedudukan Vice President CSR sangat sentral.Vice President CSR secara berkala melaporkan rencana kegiatan CSR untuk mendapatkan persetujuan dari pimpinan perusahaan. Informasi ini kemudian diterjemahkan menjadi agenda-agenda yang lebih rinci untuk dijalankan pada setiap unit bisnis BSP, termasuk BSP Unit Jambi. Vice President CSR merupakan pihak yang menjadi representasi perusahaan dalam menerima berbagai keluhan, kebutuhan, dan permintaan masyarakat.

Alasan utama BSP memilih ke-8 bidang CSR adalah kesesuaiannya dengan kebutuhan masyarakat yang bertempat tinggal di sekitar wilayah operasi perusahaan. Bidang-bidang CSR yang dijalankan oleh BSP merupakan bidang-bidang yang lazim dilaksanakan melalui CSR oleh berbagai perusahaan di dunia. Sebagian besar bidang CSR merupakan pemenuhan kebutuhan dasar, seperti pendidikan dan kesehatan, sedangkan praktik CSR di bidang ekonomi diarahkan untuk memberdayakan masyarakat.

Secara lebih spesifik, pertimbanganpertimbangan yang melatarbelakangi pelaksanaan delapan bidang CSR oleh BSP Unit Jambi sebagai berikut: (1.) memenuhi amanat pendiri Kelompok Usaha Bakrie; (2.) menjadi instrumen untuk mencapai visi dan misi perusahaan; (3.) bagian dari strategi peningkatan kinerja perusahaan, khususnya kinerja finansial; (4.) menjaga keberlanjutan bisnis perusahaan; (5.) sangat sesuai untuk memenuhi kebutuhan masyarakat; (6.) menjadi bagian dari upaya perusahaan untuk berkontribusi mengatasi permasalahan pembangunan di tingkat lokal, seperti kemiskinan, pengangguran, dan disparitas; (7.) merupakan pendekatan yang efektif untuk meredam potensi konflik; (8.) sejalan dengan regulasi pemerintah yang terkait; (9.) menjadi wahana untuk meningkatkan citra perusahaan; dan (10.) sesuai dengan best practice CSR oleh berbagai perusahaan di dunia.

BSP setiap tahunnya menganggarkan dana sebesar 1,5 persen dari net profit untuk melaksanakan CSR. Salah satu indikator yang dapat dijadikan sebagai ukuran komitmen perusahaan terhadap CSR adalah besarnya anggaran yang dialokasikan. Adapun penyerapan anggaran dapat dijadikan sebagai salah satu tolok ukur kinerja pelaksanaan CSR.

Pada tahun 2010, jumlah anggaran yang dialokasikan BSP untuk melaksanakan CSR mencapai Rp 3.987.350.625. Jumlah ini meningkat sangat tajam, yaitu 226,16 persen, jika dibandingkan dengan tahun 2009. Pada anggaran tahun 2010, perusahaan mampu merealisasikan dana CSR sebesar Rp 4.711.622.611 atau 118,16 persen. Realisasi dana CSR ini meningkat 39,87 persen jika dibandingkan dengan realisasi pada tahun sebelumnya. BSP meletakkan pendidikan sebagai fondasi bagi pengembangan masyarakat yang berkelanjutan. Besarnya 
perhatian di bidang pendidikan tercermin dari jumlah dana untuk melaksanakan berbagai kegiatan pendidikan. Pada tahun 2010, dana CSR yang direalisasikan untuk membiayai kegiatan pendidikan mencapai 21,6 persen dari total dana CSR.

Pendidikan menjadi prioritas yang diwujudkan melalui pembangunan dan renovasi gedung-gedung sekolah. Selain itu, BSP juga memberikan beasiswa dan santunan pendidikan bagi ribuan siswa dan tenaga pendidik. Penyaluran dana CSR untuk pendidikan tidak hanya terbatas pada tingkat SD, SMP, dan SMA, tetapi juga perguruan tinggi. BSP juga memberikan penghargaan bagi guru teladan, penyediaan buku bagi perpustakaan, pengadaan komputer, dan mendirikan taman bacaan. Dana yang cukup besar, maka masing-masing unitusaha BSP telah memiliki kegiatan pendidikan yang dilaksanakan secara rutin setiap tahun. Kegiatan dimaksud antara lain meliputi rehabilitasi dan pengembangan sarana pendidikan, beasiswa, honor bagi para guru teladan, pendirian, dan pembinaan yayasan pendidikan. Pemberian beasiswa menjadi prioritas dibandingkan kegiatan lainnya. Selama tahun 2010, jumlah penerima beasiswa mulai dari tingkat SD sampai dengan Perguruan Tinggi tercatat sebanyak 702 orang.

Program CSR di bidang infrastruktur dilaksanakan berdasarkan analisis terhadap kebutuhan masyarakat. Pada sisi anggaran, bidang ini menjadi prioritas kedua setelah pendidikan. Bentuk kegiatan terbaru di bidang infrastruktur adalah bedah rumah. Pada tahun 2010 terdapat tujuh unit rumah yang dibangun melalui program ini. Penanganan dampak bencana alam yang terjadi sepanjang tahun 2010 tidak luput dari perhatian. BSP memberikan bantuan tanggap bencana dan pemulihan bagi korban banjir di Karawang, tanah longsor Wasior, gempa bumi di Padang, dan letusan Gunung Merapi di Yogyakarta. Adapun kegiatan CSR di bidang kesehatan, keagamaan, kepemudaan, dan lingkungan hidup masih tetap dijalankan pada tahun 2010, tetapi skala dan ruang lingkup yang relatif sama dengan tahun-tahun sebelumnya.

Dana CSR BSP yang dialokasikan untuk Unit Jambi pada tahun 2010 berjumlah Rp 2.137.573.399,00 Jumlah ini setara dengan 53,61 persen dari total anggaran BSP untuk melaksanakan CSR sebesar Rp 3.987.350.625,00 Pada anggaran tersebut, Unit Jambi mampu merealisasikan dana CSR sebesar Rp 2.137.782.399,00 atau 100,01 persen. Jumlah dana CSR yang direalisasikan merupakan 45,37 persen dari total realisasi dana CSR BSP sebesar Rp 4.711.622.611,00 Dana CSR BSP Unit Jambi yang terbesar disalurkan untuk bidang ekonomi, yaitu sejumlah Rp 1.664.919.799,00 atau 77,88 persen dari total dana yang direalisasikan pada tahun 2010 sebesar Rp 2.137.782.399,00 Urutan kedua ditempati bidang pendidikan yang mendapatkan porsi dana Rp 245.141.000,00 atau 11,46 persen, diikuti bidang keagamaan sejumlah Rp 97.059.000,00 atau 4,54 persen.

Fakta ini menunjukkan tingginya komitmen BSP Unit Jambi untuk meningkatkan tingkat pendapatan, kondisi pendidikan, dan kualitas keagamaan masyarakat di sekitar wilayah kerjanya. Bidang CSR lainnya yang mendapatkan dana cukup besar adalah infrastruktur, yaitu Rp 56.500.000,00 atau 2,64 persen. Realisasi dana infrastruktur diharapkan dapat memperbaiki aksesibilitas masyarakat, khususnya jalan dan jembatan. Selanjutnya tiga bidang memperoleh dana yang hampir sama, yaitu kesehatan sebesar Rp 26.871.500,00 atau 1,26 persen, kepemudaan sejumlah Rp 23.291.100,00 atau 1,09 persen, dan lingkungan sebanyak Rp 20.000.000,00 atau 0,93 persen. Adapun realisasi dana yang paling kecil disalurkan untuk bidang tanggap bencana sejumlah Rp 4.000.000,00 atau 0,19 persen.

Realisasi dana CSR BSP Unit Jambi mengalami fluktuasi dari tahun ke tahun. Tahun 2010 merupakan periode di mana terjadi lonjakan drastis dalam realisasi dana CSR. Sebagai perbandingan, realisasi dana CSR pada tahun 2006 baru sebesar 
Rp 129.079.000,00 yang setara dengan 97,60 persen dari dana yang dialokasikan sejumlah Rp 132.250.000,00 Pada tahun 2007, realisasi dana CSR meningkat menjadi Rp 180.515.642, 00 dan menurun menjadi Rp 154.000.000,00 atau 71,46 persen dari yang dianggarkan sebesar Rp 215.500.000,00 Di tahun 2009, pada perencanaan, alokasi dana CSR ditingkatkan menjadi Rp 259.000.000,00 tetapi realisasinya ternyata hanya $\mathrm{Rp} 137.385 .745,00$ atau 53,04 persen dari rencana.Penerapan pola Kemitraan Inti-Plasma sebagai instrumen CSR sangat unik. Substansi Kemitraan IntiPlasma mampu memenuhi makna dari tanggung jawab sosial yang dijalankan perusahaan yang dikemukakan sejak lama oleh berbagai peneliti. Para peneliti yang dimaksud antara lain Carrol (1979), Wood (1991) dalam Jones (2005), Elkington (2004), Morimoto dalam (2004), Heal (2005), Marshall (2005), Quevedo-Puente dalam (2007), Crowther dan Aras (2008), serta Suharto (2008).

Kemitraan Inti-Plasma dipandang paling sesuai pada kondisi BSP sebagai perkebunan kelapa sawit berskala besar. Pada saat BSP berumur 100 tahun, luas lahan plasma di Kabupaten Tanjung Jabung Barat, Provinsi Jambi, tercatat mencapai 7.701 ha atau 65 persen, sedangkan luas lahan inti lebih kecil, yaitu 4.418 ha atau 35 persen. Terdapat dua tipe kemitraan yang dijalankan, yaitu (1) Pola Inti-Plasma Pertanian Inti Rakyat (PIR) Trans (masyarakat transmigrasi); dan (2) Pola Inti-Plasma Kredit Koperasi Primer Anggota (KKPA, masyarakat lokal).

Perusahaan telah membina 23 koperasi, termasuk 8 koperasi karyawan hingga 2010. Jenis kegiatan CSR di bidang ekonomi yang baru dikembangkan pada tahun 2010 adalah pembinaan UKM Makanan Ringan di BSP Unit Sumut I serta kemitraan dengan koperasi plasma di Unit Jambi I dan Unit Sumbar. Selain kemitraan dengan koperasi, BSP Unit Jambi mulai melakukan pemberdayaan ekonomi di sebuah lembaga pendidikan keagamaan, yaituPondok Pesantren Riyadhusholihin. Pondok Pesantren Riyadhusholihin mendapatkan bantuan ternak kambing yang dimanfaatkan oleh para santri untuk belajar menjadi pelaku agribisnis.

Penghimpunan petani plasma di dalam wadah koperasi dimaksudkan agar proses pembinaan dapat dilakukan secara efektif. Dalam konteks ini, koperasi diposisikan sebagai mitra kerja dan sekaligus binaan. Pembinaan yang dilakukan oleh BSP Unit Jambi mencakup penguatan organisasi dan personilnya, melakukan pengawasan/ pengendalian, dan melaksanakan pelatihan khususnya mengenai prosedur kerja. Pembinaan dijalankan secara berkesinambungan dan dilengkapi dengan penyuluhan yang dilakukan oleh pihak perusahaan maupun dengan mendatangkan pihak luar yang berkompeten.Kemitraan Inti-Plasma yang diwadahi di dalam koperasi terbukti secara empirik mampu meningkatkan pendapatan petani dan mengurangi kemiskinan. Setiap petani telah memiliki kebun dengan luas rata-rata 1,5-2,0 ha per-Kepala Keluarga, sedangkan kepada Desa diberikan kesempatan untuk memiliki Tanah Kas Desa seluas rata-rata 10 ha perdesa.

Contoh konkret adalah KUD Maju Lancar dan KUDSuka Makmuryang memiliki kinerja sangat baik dan bahkan pernah meraih penghargaan sebagai KUD terbaik se-Provinsi Jambi. Ketika diteliti, KUD Maju Lancar memiliki 252 anggota dengan aset Rp 501 juta. Sementara itu, KUD Suka Makmur mampu menghimpun 1.977 orang dengan aset lebih dari Rp 4 miliar. Jenis kegiatan yang dilaksanakan kedua KUD terdiri dari simpan pinjam, warung serba ada (waserda), sarana produksi pertanian (saprotan), angkutan, dan usaha-usaha lainnya yang berkaitan dengan kebutuhan petani plama sebagai anggota. Keberhasilan BSP Unit Jambi mengelola plasma berpengaruh nyata terhadap kehidupan masyarakat plasma dan telah menjadi contoh di tingkat nasional.

Ketika pertama kali datang ke Kecamatan Tebing Tinggi, Kabupaten Tanjung Jabung Barat, Provinsi Jambi pada tahun 1984, ratusan transmigran asal Jawa Tengah dan Jawa Timur di beberapa desa harus menghadapi 
kenyataan pahit. Perjuangan hidup yang dijalani sangat berat, tidak seperti yang dibayangkan. Sebagian besar wilayah desa yang dihuni masih berupa hutan dan akses ke dunia luar sangat terbatas.

Para transmigran pada umumnya bertanam palawija karena lahan yang disediakan tidak dapat ditanami padi. Hasil panen palawijapun seringkali kurang memuaskan dan tidak jarang tidak dapat dijual karena perjalanan menuju Kota Jambi berjarak lebih dari $125 \mathrm{~km}$. Masih banyak hama yang mengganggu produksi tanaman, terutama monyet dan babi hutan. Warga desa terjebak di dalam kondisi kemiskinan yang akut, sehingga tidak mampu membeli beras karena dianggap terlalu mahal dan sulit diperoleh. Selain itu, banyak anak-anak yang tidak dapat mengenyam pendidikan dasar dengan layak.

Setelah lebih dari satu dekade, yaitu pada tahun 1995, barulah terlihat titik terang. Program Kemitraan Sawit yang dikelola PT. Agrowiyana, salah satu anak perusahaan BSP Unit Jambi, mulai memasuki wilayah desa transmigrasi. Kemitraan dijalankan dengan menanggung sebagian bunga bank (subsidi bunga) yang harus dibayarkan oleh petani plasma. Perusahaan juga melakukan pembinaan dengan menugaskan mandor blok untuk setiap luasan lahan. Setiap mandor bertugas membina petani, khususnya menyangkut kegiatan penanaman bibit kelapa sawit, pemupukan, pemanenan, dan lain sebagainya.

Ketika pohon kelapa sawit mulai berbuah dalam kurun 4 tahun, petani plasma baru diperkenankan mulai membayar utangnya dengan sistem cicilan. Besarnya cicilan yang ditetapkan oleh BSP Unit Jambi adalah 35 persen dari total pendapatan, yaitu penjualan tandan buah segar (TBS) perbulan. Pada saat dilakukan penelitian ini, ribuan petani plasma yang menjadi mitra telah melunasi utangnya.

Menurul Kamaluddin, salah seorang Staf PT. Agrowiyana yang menangani Kemitraan Inti-Plasma, kehidupan para petani plasma telah berubah 180 derajat dengan hasil yang diperoleh dari kemitraan sawit. Rata-rata tingkat pendapatan tiap keluarga petani plasma yang memiliki satu kavling kebun kelapa sawit atau setara 2 ha mencapai $\operatorname{Rp}$ 2,5-3 juta per-bulan. Ditambahkan oleh Sutejo selaku Ketua KUD Suka Makmur (Desa Purwodadi, Kecamatan Tebing Tinggi), terdapat petani plasma yang memiliki 9 kavling, sehingga pendapatannya bisa mencapai Rp15 juta hingga Rp30 juta perbulan.

Lebihjauh menurutSutejo, sebagian besar penduduk sudah sejahtera. Para petanipun sangat tinggi kesadarannya di bidang pendidikan. Seratus persen lulusan SMA di Purwodadi meneruskan pendidikannya ke perguruan tinggi di Jawa dan Sumatera. Dari hasil mengikuti program kebun plasma, banyak penduduk desa yang tercukupi kebutuhan pokoknya. Semua penduduk di Purwodadi telah memiliki kendaraan roda dua dan lebih dari 40 persen memiliki kendaraan roda empat. Rumah-rumah yang bersifat permanen secara bertahap telah menjamur di seluruh bagian desa.

Pelaksanaan CSR di bidang ekonomi bervariasi setiap tahun dan semakin komprehensif. Pada tahun 2006, BSP Unit Jambi hanya mengadakan 1 unit truk kepada petani plasma sebagai bantuan untuk mengangkut tandan buah segar kelapa sawit. Namun, pada tahun 2007, perusahaan telah memulai kemitraan dengan para pelaku usaha kecil dan menengah dengan jenis kegiatan meliputi pelatihan kinerja pengelolaan koperasi, pelatihan pertanian terpadu, pasar murah Ramadhan, penebaran bibit ikan, dan menyediakan dana untuk perawatan kebun.

Kegiatan CSR di bidang ekonomi terus berkembang pada tahun 2008. Di tahun ini, perusahaan masih melakukan pelatihan pengelolaan koperasi dan pelatihan pertanian terpadu. Kegiatan lainnya adalah penebaran bibit ikan patin dan nila. Selanjutnya, pada tahun 2009, kegiatan CSR di bidang ekonomi terdiri dari pelatihan kemitraan bagi petani kelapa sawit dan dimulainya kemitraan dengan petani ikan. 
Setiap kegiatannya, BSP senantiasa mengedepankan etika bisnis dan tata kelola perusahaan yang baik yang mengacu pada prinsip-prinsip GCG. Selain itu, 3 unsur dalam Triple Bottom Line, yakni people, profit, dan planet juga dijadikan sebagai acuan kegiatan bisnis. BSP memahami bahwa karyawan dan keluarganya merupakan stakeholders yang memiliki peran yang sama pentingnya dengan komunitas di luar perusahaan.

\section{Manfaat CSR}

Berbagai kegiatan CSR sangat penting, karena apabila kondisi masyarakat di sekitar perusahaan telah kuat dan kondusif, maka upayameningkatkankinerja perusahaantidak akan terganggu. Pemikiran Wisena (Anonim, 2007: 5), kepercayaan dan reputasi tidaklah gratis, sehingga perusahan harus respek dan berupaya meraihnya. CSR merupakan salah satu alat untuk meningkatkan reputasi perusahaan. Sedangkan menurut Sebayang (Anonim, 2007: 9), plasma Jambi telah menjadi barometer di daerah dan bahkan nasional. Kemitraan Inti-Plasma telah membangun ekonomi masyarakat melalui pemberdayaan, sehingga masyarakat mampu meningkatkan kesejahteraannya secara mandiri. Kemitraan yang terjadi telah mendarah daging di kalangan petani plasma.

Sargeant (Anonim, 2008: 5) mengatakan bahwa CSR sangat penting untuk mendukung pencapaian target BSP menjadi perusahaan multinasional. BSP memiliki komitmen untuk menjadi leader in market. Ketika banyak pihak belum memulai, BSP telah menjalankan CSR. Tujuannya agar perusahaan dapat membangun partnership yang baik dengan masyarakat dan ikut membangun daerah.

Kemitraan Inti-Plasma dipandang oleh masyarakat sebagai jalan menuju kesejahteraan. Keberhasilan BSP Unit Jambi dalam menyelesaikan konversi dan pelunasan kredit plasma secara tepat waktu merupakan suatu kebanggaan bagi petani maupun perusahaan. Kerjasama yang saling menguntungkan seperti ini perlu dipertahankan, bahkan lahan-lahan kelapa sawit di luar plasma perlu diajak untuk bergabung dalam kemitraan.

Tugas perusahaan adalah memberdayakan petani plasma dan memaksimalkan produksi. Selain itu, perusahaan berusaha menjaga kesinambungan produksi hingga umur tanaman kelapa sawit mencapai 25-30 tahun. Perusahaan secara moral melakukan pembinaan untuk mencerahkan wawasan dan mengubah cara berpikir petani dari perkebunan tradisional menjadi pola pikir perkebunan modern, sehingga produktivitas dapat ditingkatkan. Koperasi juga merupakan bagian integral dari pola Kemitraan Inti-Plasma.

Banyakhalyangtelahdicapaimasyarakat dari hasil plasma, yaitu mencakup perbaikan ekonomi, infrastruktur, pendidikan, sosial, dan sebagainya.Pada waktu lampau, kebanyakan rumah masyarakat dapat dikatakan tidak layak huni. Dewasa ini, telah banyak dijumpai rumah permanen dan petani plasma juga telah memiliki kendaraan.

Pada tahun 2009, BSP Unit Jambi merenovasi bangunan SD dan laboratorium, serta menyediakan alat peraga pendidikan. Selain itu, perusahaan juga mengembangkan kemitraan dengan peternak sapi dan pandai besi binaan. Masih pada tahun yang sama, BSP Unit Jambi melakukan penebaran bibit ikan patin dan ikan nila untuk memberdayakan kelompok nelayan, memberikan dana bergulir untuk usaha warung di SD, memberikan bantuan buku bacaan agama, serta beberapa kegiatan pembangunan infrastruktur (jalan desa, pembangunan kantor pesantren, dan pembuatan benteng jalan).

Selanjutnya, pada tahun 2010, BSP Unit Jambi memberikan bantuan yang meliputi bidang pendidikan, ekonomi, dan infrastruktur. Bidang pendidikan diberikan bantuan alat peraga SD dan SMP, sedangkan di bidang ekonomi adalah penyerahan ternak sapi kepada Karang Taruna. Selain itu, diserahkan pula bantuan renovasi pos keamanan dan ketertiban kepada Pos Polisi Sektor setempat, perbaikan infrastruktur jalan dan jembatan kebun plasma, serta 
renovasi sarana ibadah masjid dan gereja. Sebagai pelengkap, juga diserahkan bantuan peralatan olahraga, peningkatan gizi di posyandu lanjut usia, dan bakti sosial TNI.

Kemitraan Inti-Plasma terus dijaga karena perusahaan dan masyarakat saling membutuhkan. Lebih dari sepertiga kebun kelapa sawit yang dikelola merupakan kebun plasma. Kesulitan terbesar yang dihadapi petani plasma adalah minimnya pengetahuan dalam berkebun dengan baik. Petani sering memanen kelapa sawit yang masih mentah karena lebih mementingkan kuantitas dibandingkan kualitas. TBS yang mentah akan menghasilkan $\mathrm{CPO}$ yang kurang baik dan tanaman mengalami stress.

Masalah lainnya adalah harga penjualan TBS kelapa sawit. Petani plasma seringkali menuntut harga yang tidak sesuai dengan kualitas TBS kelapa sawit yang dihasilkannya. Banyak kualitas TBS kelapa sawit yang tidak mencapai 95 persen dari standar, sebagai akibat penanganan pascapanen yang kurang baik. Akan tetapi, BSP Unit Jambi selaku inti harus menjadi pengayom dan pelindung bagi para petani plasma.

Berdasarkan survei terhadap 456 petani plasma diperoleh jawaban yang beragam mengenai Program CSR yang diterima. Sebagian besar responden, yaitu 368 orang atau 80,70 persen menyatakan hanya pernah menerima 1 bidang kegiatan CSR, sedangkan responden yang mengemukakan pernah menjadi penerima manfaat lebih dari 1 bidang CSR sebanyak 41 orang atau 8,99 persen. Selain itu, 47 responden atau 10,31 persen tidak dapat menyebutkan nama Program CSR yang pernah diterima dari BSP Unit Jambi.

Mayoritas responden yang berjumlah 205 orang menyatakan telah menerima bantuan CSR untuk bidang infrastruktur. Kemudian 161 responden mengemukakan telah menerima bantuan ekonomi, sedangkan 57 responden telah menerima bantuan kesehatan. Responden lainnya sejumlah 28 orang mengungkapkan pernah mendapatkan dana CSR untuk bidang keagamaan. Selanjutnya masing-masing 21 responden menyatakan telah merasakan kegiatan pendidikan dan lingkungan. Adapun 2 responden lainnya mengaku mengetahui bahwa terdapat dana CSR yang digunakan untuk kegiatan kepemudaan.

Jenis kegiatan CSR di bidang infrastruktur meliputi pembuatan goronggorong, perawatan jalan, pengerasan jalan, perbaikan jalan (jalan poros dan jalan produksi), perbaikan jembatan, bantuan semen, pembuatan batas blok, bantuan alat berat, dan bantuan renovasi madrasah. Sementara itu, untuk bidang lingkungan, jenis-jenis kegiatan yang dilaksanakan adalah pembuatan sumur bor untuk masyarakat. Untuk bidang kepemudaan, jenis kegiatan yang diterima oleh responden adalah tiang gawang sepakbola dan bantuan alat olahraga SD.

Selanjutnya, jenis-jenis kegiatan di bidang keagamaan terdiri dari bantuan pembangunan dan renovasi masjid, safari ramadhan, serta pemberian uang tali asih. Sementara itu, untuk bidang kesehatan, dana CSR digunakan untuk melaksanakan sunatan massal, bantuan posyandu, penyuluhan dan pemeriksaan kesehatan jantung, penyemprotan nyamuk, sosialisasi perawatan atau peningkatan kesehatan, dan pengobatan gratis. Adapun di bidang pendidikan, responden menyatakan menerima bantuan berupa beasiswa untuk murid SD yang berprestasi, bantuan alat peraga sekolah, dan bantuan sarana sekolah.

Variasi kegiatan CSR yang terbanyak adalah di bidang ekonomi. Program CSR yang disalurkan dalam bentuk uang tunai maupun berbagai jenis bantuan barang. Jenis-jenis kegiatan di bidang ekonomi mencakup pembinaan koperasi, optimalisasi lahan pertanian, bantuan itik, demplot pertanian, bantuan benih ikan, bantuan bibit tanaman sayur dan palawija, bantuan pupuk, bantuan ternak kambing, pembinaan kerajinan membatik (pemberdayaan kaum perempuan), pemanfaatan lahan pekarangan, serta bantuan pembuatan dan pembinaan pengelolaan kebun kelapa sawit. Selain itu, diberikan pula insentif untuk pengurus 
kelompok tani, pembinaan penanganan pasca panen kelapa sawit, pemberian pinjaman (kredit) lunak, pemberian bibit kelapa sawit untuk para petani plasma, dan pemberdayaan petani plasma selaku mitra kerja.

Sedikit berbeda dengan responden penerima manfaat, karyawan BSP Unit Jambi yang dijadikan sebagai responden menyebutkan bahwa Program CSR mencakup berbagai bidang. Sebanyak 15 responden karyawan menyatakan bahwa BSP Unit Jambi telah menyalurkan dana untuk mendukung kegiatan pendidikan, sedangkan 9 responden lainnya mengemukakan bidang ekonomi. Selanjutnya terdapat masingmasing 11 responden dan 14 responden yang mengungkapkan bahwa dana CSR telah dimanfaatkan untuk bidang kesehatan dan keagamaan. Bidang kepemudaan diutarakan oleh 5 responden, sedangkan bidang lingkungan dan infrastruktur dinyatakan oleh masing-masing 3 responden dan 15 responden.

Responden petani plasma menyatakan telah menerima Program CSR sejak tahun 2000 hingga 2011. Jumlah responden terbanyak, yaitu 81 orang atau 17,76 persen dari total 456 responden, menyatakan telah menerima Program CSR sejak tahun 2001. Di urutan kedua adalah 54 responden atau 11,84 persen yang telah menerima Program CSR sejak tahun 2008. Selanjutnya, 52 responden atau 11,40 persen telah menerima bantuan CSR sejak tahun 2004.

Posisi keempat ditempati oleh 48 responden atau 10,53 persen yang telah menikmati bantuan CSR sejak tahun 2003 dan 2007. Responden lainnya sejumlah 38 orang atau 8,33 persen telah menerima Program CSR sejak tahun 2002 dan diikuti oleh 37 responden atau 8,11 persen yang telah menjadi penerima manfaat sejak tahun 2006. Kemudian terdapat 29 responden atau 6,36 persen dan 24 responden atau 5,26 persen yang masing-masing mengaku telah menerima bantuan CSR sejak tahun 2010 dan 2009. Adapun 23 responden atau 5,04 persen menjadi penerima manfaat CSR sejak tahun 2005. Dua kelompok responden yang terakhir, yaitu masing-masing 17 orang dan 5 orang mengemukakan telah memperoleh manfaat dari dana CSR BSP Unit Jambi sejak tahun 2000 dan 2011.

Responden karyawan mengemukakan informasi yang berbeda. Mayoritas responden, yaitu 7 orang atau 43,75 persen menyatakan bahwa Program CSR telah dimulai sejak tahun 2001. Di urutan kedua adalah 3 responden atau 18,75 persen yang mengungkapkan bahwa Program CSR telah dimulai sejak tahun 2006. Kemudian masingmasing 2 responden atau 12,50 persen yang menyebut tahun 1995 dan 2006 sebagai periode dimulainya Program CSR oleh BSP Unit Jambi. Di urutan terakhir adalah masing-masing 1 responden atau 6,25 persen yang mengemukakan bahwa Program CSR dimulai pada tahun 2004 dan 2005.

Harnuni, Kepala Desa Brasau, menceritakan bahwa di Desa Brasau pada awalnya terdapat $100 \mathrm{kk}$ transmigran pada tahun 2000. Kemudian, pada tahun 2001, datang lagi $100 \mathrm{kk}$ transmigran dari luar daerah maupun lokal. Pada tahun 2002, bertambah lagi sebanyak 33 kk transmigran, sehingga jumlah warga desa pada awalnya 237 kk.Masyarakat pada awalnya bekerja sebagai buruh tani harian di perusahaan dengan upah $\mathrm{Rp} 6.000,00$ perhari dan dijanjikan bahwa kebun yang digarap akan menjadi milik petani.Untuk menyambung hidupnya, antara tahun 20002002, masyarakat masih bergantung kepada bantuan pemerintah (jatah hidup).

Keadaan ini mengalami perubahan sejak tahun 2002, ketika perusahaan mulai membagikan kebun (konversi). Secara bertahap, pendapatan petanimenjadi berbeda dengan tahun-tahun sebelumnya. Sebagai perbandingan, pada tahun 2002, pendapatan masyarakat rata-rata berkisar Rp 600.000,00 perbulan. Sekarang, jika kredit telah lunas, rata-rata pendapatan bersih petani dapat mencapai Rp 3.500.000,00 perbulan dengan asumsi produksi lahan kelapa sawit masingmasing minimal 3,5 ton.

Fasilitas desa di Desa Brasau dahulu hanya terdiri dari Kantor Desa, Kantor 
Koperasi, gudang, Balai Desa, dan Masjid. Sekolah kemudian dapat dibangun secara swadaya dan saat ini masyarakat bahkan telah memiliki mesin diesel sendiri untuk memasok kebutuhan listrik. Desa Brasau bahkan pernah menjadi percontohan pengembangan BMT pada tahun 2003 dan mendapatkan bantuan modal Rp 200.000.000,00. Dengan terjalinnya hubungan yang baik di antara petani plasma, dengan perusahaan selaku inti, dan KUD, maka kegiatan kemitraan yang didukung pembinaan secara intensif dapat berjalan dengan lancar, sehingga produksi TBS kelapa sawit juga meningkat.

Menurut Haryoko, Bendahara KUD Suka Makmur bahwa bantuan perusahaan seperti portal, membantu keamanan kebun, dan buah sawit petani plasma. Selain itu, banyak keuntungan lain yang diperoleh petani plasma, sehingga CSR diharapkan dapat berkelanjutan. Curah pendapat juga disampaikan oleh M. Kholil, petani dan Sekretaris KUD Maju Lancar. Menurutnya, selain kemitraan, masih banyak program CSR yang dijalankan perusahaan, seperti perbaikan jalan dan penyuluhan. Kondisi kemajuan ekonomi masyarakat saat ini sangat berbeda dibandingkan jaman dulu. Jika rata-rata petani mampu memanen 3 ton TBS kelapa sawit, maka pendapatannya lebih dari Rp 3.000.000,00 perbulan karena harga TBS mencapai 1.200 hingga 1.300 rupiah perkilogram.

Persepsi positif juga terungkap dalam wawancara dengan tiga aparat pemerintah. Kepala Bidang Pengembangan Sumberdaya dan Kelembagaan, Dinas Perkebunan Kabupaten Tanjung Jabung Barat melihat CSR sebagai suatu upaya berkelanjutan yang dilakukan BSP Unit Jambi untuk memberdayakan petani plasma kelapa sawit. Contohnya adalah bantuan penyediaan pupuk dan perbaikan jalan produksi. Disarankan agar perusahaan melengkapi kegiatan CSR dengan pengadaan obatobatan untuk membasmi hama penyakit.

CSR yang dijalankan dapat memberikan manfaat yang lebih luas dan tidak hanya di bidang ekonomi. Sebagai contoh, CSR dapat mendukung upaya Pemerintah Kabupaten Tanjung Jabung Barat dalam mencapai pemerataan pendidikan kepada semua anak usia sekolah. Pemberian beasiswa merupakan salah satu bentuk nyata dari kontribusi BSP Unit Jambi di bidang pendidikan. Kegiatan lainnya yang sangat bermanfaat adalah pemberian bantuan dalam bentuk pembangunan sumur air bersih.

Akan tetapi, diingatkan agar BSP Unit Jambi dapat mengkomunikasikan rencana CSR secara rinci kepada instansi-instansi pemerintah daerah yang terkait. Tujuan utamanya agar tidak terjadi tumpang tindih dengan berbagai program dan kegiatan pembangunan yang dilaksanakan oleh pemerintah daerah. Jika dikomunikasikan dengan baik, maka pemerintah daerah dan BSP Unit Jambi dapat saling mengisi, sehingga kegiatan pembangunan dapat dilakukan secara efisien dan efektif.

Menurt Camat Tebing Tinggi, keberadaan BSP Unit Jambi sangat membantu perbaikan kehidupan masyarakat di wilayahnya. Banyak anggota masyarakat yang dulunya masih hidup di bawah kondisi kemiskinan, kini dengan adanya perusahaan, sudah mampu hidup lebih baik. Kegiatan CSR sangat bagus dan dapat disebut sebagai sedekah (zakat) dari perusahaan. Camat Tebing Tinggi sangat terkesan dengan program-program CSR yang mampu membantu perbaikan kondisi ekonomi masyarakat. Bila perusahaan konsisten dalam melaksanakan kegiatan CSR dan tepat sasaran, maka diyakini bahwa perusahan akan mendapat keuntungan yang lebih besar. Akan tetapi, perusahaan diharapkan lebih transparan kepada Pemerintah Kecamatan Tebing Tinggi dalam menjalankan CSR-nya.

Pandangan serupa mengemuka dalam wawancara dengan Camat Tungkal Ulu. Program CSR dikatakan sangat bagus karena membantu perekonomian di Kecamatan Tungkal Ulu. Misalnya, Program Koperasi Kredit Primer Anggota (KKPA) yang sangat efektif dalam memberdayakan masyarakat dari sisi ekonomi. Secara umum, keberadaan perusahaan sangat membantu perbaikan 
kualitas hidup masyarakat.CSR menurutnya adalah perwujudan kepedulian perusahaan terhadap masyarakat sekitar. Di masa mendatang, diharapkan adanya kerjasama yang lebih erat di antara BSP Unit Jambi dengan Pemerintah Kecamatan Tungkal Ulu dalam pelaksanaan CSR.

Program CSR diharapkan dapat membantu memperbaiki kondisi sosial dan ekonomi, di samping meningkatkan interaksi positif di antara BSP Unit Jambi dengan masyarakat. Interaksi positif menciptakan suasana yang kondusif, sehingga usaha yang dijalankan menghasilkan produktivitas yang tinggi dan kinerja keuangan senantiasa bertumbuh. Citra perusahaan turut terangkat di dalam dan luar negeri.

Dari 456 responden, diketahui bahwa tidak ada satupun responden yang sangat tidak setuju dan tidak setuju terhadap manfaat Program CSR. Namun, terdapat 32 responden atau 7,02 persen yang memilih netral. Mayoritas responden, yaitu 336 orang atau 73,68 persen setuju bahwa CSR memberikan manfaat. Responden lainnya sebanyak 88 orang atau 19,30 persen sangat setuju. Jika jumlah responden yang setuju dan sangat setuju digabungkan, maka dihasilkan 424 orang atau 92,98 persen yang menyetujui adanya manfaat yang dihasilkan dari pelaksanaan berbagai kegiatan CSR di wilayah tempat tinggalnya.

Kecenderungan jawaban yang sama dihasilkan dari survei terhadap karyawan BSP Unit Jambi. Sejumlah 8 responden atau 50,00 persen setuju bahwa CSR memberikan manfaat kepada masyarakat. Selanjutnya 7 responden atau 43,75 persen sangat setuju dan hanya 1 responden atau 6,25 persen yang bersikap netral. Dengan menjumlahkan responden yang setuju dan sangat setuju, diketahui bahwa 15 dari 16 responden atau 93,75 persen menyetujui adanya manfaat dari Program CSR yang dirasakan oleh masyarakat.

Sebagian responden hanya menyebutkan 1 bentuk manfaat, sedangkan responden lainnya menyatakan merasakan lebih dari 1 bentuk manfaat CSR. Tercatat 388 responden petani plasma yang merasakan manfaat CSR berupa peningkatan pendapatan. Sejumlah 136 responden lainnya mengemukakan perluasan kesempatan kerja sebagai manfaat yang dirasakan. Selanjutnya 103 responden merasakan peningkatan pendidikan dan 85 responden mengungkapkan peningkatan kesehatan sebagai manfaat dari implementasi CSR. Sebagian kecil responden menyatakan bentuk manfaat yang lain, yaitu pengiriman TBS yang menjadi lebih lancar (2 responden), peningkatan pengetahuan (1 responden), bantuan dana tunai untukjalan (1 responden), dan pendidikan (1 responden).

Untuk responden karyawan BSP Unit Jambi, semuanya menyatakan peningkatan pendapatan adalah manfaat dari CSR. Peningkatan pendapatan disebutkan oleh 15 responden bersama-sama dengan 3 alternatif bentuk manfaat lainnya, yaitu perluasan kesempatan kerja, serta peningkatan pendidikan dan kesehatan. Hanya 1 responden yang mengemukakan hanya 2 bentuk manfaat, yaitu peningkatan pendapatan dan pendidikan. Selain itu, terdapat 7 responden yang mengungkapkan bentuk-bentuk lain dari 4 alternatif pilihan manfaat implementasi CSR, yaitu terciptanya hubungan kekeluargaan, kesejahteraan masyarakat, infrastruktur menjadi lebih baik, keagamaan, dan peningkatan hubungan kemitraan.

Bentuk manfaat lainnya dari CSR di lingkungan perusahaan adalah reboisasi hutan konservasi. BSP Unit Jambi sangat memperhatikan keberadaan dan fungsi hutan konservasi demi terjaganya kelestarian alam. Walaupun bergerak di bidang perkebunan, namun perusahaan tetap mempertahankan beberapa lokasi hutan konservasi. Hutan konservasi di wilayah operasi BSP Unit Jambi memiliki luas 18,85 ha dan terletak di sekitar perumahan karyawan. Hutan ini dilindungi oleh perusahaan dengan mengajak seluruh karyawan untuk bersama-sama menjaga dan melindungi kelestarian ekosistem di dalamnya. Selain hutan konservasi, perusahaan telah menanam 1.000 batang pohon jati.

Perusahaan juga menanam tanamantanaman lainnya, seperti pohon beringin, buah-buahan, serta tamanan hias. Kesadaran 
akan pentingnya fungsi hutan konservasi telah tertanam cukup baik pada diri setiap karyawan perusahaan. Karyawan juga memanfaatkan pekarangan yang kosong dengan menanam sayur-sayuran. Perusahaan dari waktu ke waktu selalu berupaya memanfaatkan wilayah kosong dan semak belukar di sekitar kantor dan perumahan karyawan dengan berbagai jenis tanaman yang dapat menghasilkan.

Peningkatan pendapatan secara signifikan merupakan indikator membaiknya kesejahteraan masyarakat dari segi ekonomi. Sebaliknya,jikahasilujistatistikmenunjukkan tidak adanya perbedaan pendapatan yang nyata, maka fakta ini merupakan indikasi bahwa pelaksanaan Program CSR oleh BSP Unit Jambi belum optimal, setidak-tidaknya dalam konteks memperbaiki kondisi perekonomian masyarakat.

Hasil analisis statistik deskriptif menunjukkan bahwa rata-rata penghasilan masyarakat sebelum menjadi plasma, yaitu pada tahun 2000 berjumlah Rp 477.888,00 perbulan, dengan median $\mathrm{Rp}$ 350.000,00 perbulan. Penghasilan terkecil adalah Rp 75.000,00 sedangkan penghasilan tertinggi $\mathrm{Rp}$ 3.000.000,00 Rasio antara rata-rata penghasilan perbulan yang terbesar dengan yang terkecil mencapai 40 kali dengan standar deviasi yang cukup besar, yaitu Rp 385.335,00 Fakta ini menunjukkan adanya kesenjangan penghasilan yang lebar di antara masyarakat yang bertempat tinggal di wilayah operasi BSP Unit Jambi sebelum menjadi petani plasma.

Sepuluh tahun kemudian, setelah menjadi petani plasma, pendapatan masyarakat mengalami peningkatan yang sangat pesat. Rata-rata penghasilan petani plasma perbulan telah mencapai $\mathrm{Rp}$ 2.691.700,00 dengan median Rp 2.500.000,00 Berarti dalam kurun waktu 10 tahun terjadi peningkatan pendapatan masyarakat 5,63 kali. Rasio ini mengkonfirmasi pandangan kebanyakan responden yang merasakan peningkatan pendapatan atau kesejahteraan ekonomi merupakan bentuk manfaat CSR yang paling nyata.
Penghasilan rata-rata perbulan yang terkecil dari responden petani plasma berjumlah $\mathrm{Rp} \quad 325.000,00$ sedangkan penghasilan tertinggi sebesar Rp12.000.000,00 Berarti rasio di antara keduanya mencapai 36,92 kali. Apabila ditambah dengan standar deviasi Rp 1.394,71 membuktikan bahwa meskipun mengalami sedikit penurunan, tetapi disparitas pendapatan di antara masyarakat masih tinggi. Program CSR telah mampu meningkatkan pendapatan masyarakat secara signifikan, tetapi belum mampu mengatasi kesenjangan pendapatan.

Hasil uji kesamaan rata-rata menunjukkan bahwa secara statistik terjadi perbedaan pendapatan masyarakat setelah terlibat di dalam Kemitraan Inti-Plasma perkebunan kelapa sawit dengan BSP Unit Jambi. Harnuni, Kepala Desa Brasau, tidak pernah bisa melupakan kondisi warganya pada awal tahun 2000-an yang kebanyakan terbelit kemiskinan. Kini, kondisi masyarakat telah berubah drastis berkat partisipasi pada Kemitraan Inti-Plasma. Pendapatan masyarakat telah meningkat secara nyata.

Perbaikan kondisi kehidupan mendorong masyarakat untuk senantiasa berharap agar harga TBS kelapa sawit dan kinerja bisnis BSP Unit Jambi selalu membaik. Masyarakat telah mulai menyadari bahwa perbaikan bisnis BSP Unit Jambi akan secara langsung memberikan dampak ikutan terhadap pendapatan mereka. Untuk itu, pengelolaan kebun kelapa sawit juga perlu dilakukan dengan baik agar dapat selalu memasok TBS bagi pabrik sesuai dengan kapasitas pengolahan. Fenomena ini merupakan bukti aktual simbiosis mutualisme.

Kemitraan Inti-Plasma juga diterapkan oleh BSP Unit Jambi di desa-desa lainnya di KecamatanTungkalUlu.Didesa-desa lainpun diperoleh hasil yang kurang lebih sama dengan di Desa Brasau. Berdasarkan fakta ini, maka banyak pihak menilai pemberdayaan masyarakat melalui Kemitraan Inti-Plasma kelapa sawit yang dilakukan oleh BSP Unit Jambi berhasil mengangkat derajat kehidupan masyarakat. Jika Kemitraan Inti- 
Plasma mampu memberikan manfaat bagi seorang kepala keluarga, maka dampak yang diberikan akan mencakup pula anggota keluarga yang rata-rata berkisar 4-5 orang di setiap rumah tangga.

Secara teknis, BSP Unit Jambi menjalankan Kemitraan Inti-Plasma kelapa sawit dengan memberikan pelatihan dan pendampingan kepada masyarakat. Upaya ini ditempuh mulai dari pembersihan lahan, penanaman bibit, penanganan panen, hingga pengangkutan TBS kelapa sawit ke pabrik. Semua hasil panen dari petani plasma dijual ke perusahaan sesuai dengan harga pasar. Saat ini, konversi lahan telah diselesaikan, sehingga semua petani plasma memiliki lahan sendiri seluas antara 1,5 ha hingga 2,0 ha. Lahan ini dapat dijadikan sebagai agunan untuk mendapatkan pinjaman dari perbankan.

Tersedianya aset dan perbaikan pendapatan hingga lebih dari dua kali lipat menyebabkan kemiskinan dapat dientaskan. Pendapatan masyarakat juga lebih pasti, sehingga dapat merencanakan masa depannya dengan lebih baik. Petani plasma dapat melakukan panen hingga dua kali dalam satu bulan dengansetiap hektare lahan kebun kelapa sawit dapat menghasilkan pendapatan rata-rata sekitar Rp2,5 juta perbulan. Jika harga minyak kelapa sawit dunia mengalami peningkatan, maka pendapatan masyarakat juga ikut terdongkrak.

Perbaikan pendapatan masyarakat membawa efek berganda bagi pembangunan wilayah. Peningkatan daya beli membuat perputaran uang dan barang menjadi lebih cepat, sehingga perekonomian lokal menjadi lebih dinamis. Banyak bank yang membuka kantor cabangnya di Kecamatan Tungkal Ulu.

Praktik CSR yang dijalankan oleh BSP Unit Jambi juga merupakan perwujudan dari pembangunan berbasis komunitas atau community based development (CBD) karena Kemitraan Inti-Plasma sejalan dengan tahaptahap implementasi CBD. Berbagai tahap dimaksud terdiri dari seleksi jenis usaha, studi kelayakan, perekrutan binaan, pelatihan, bantuan modal usaha (melalui KUD), dan pembinaan pasca kegiatan. Pembinaan mencakup penguasaan keterampilan, motivasi dan etos kerja, manajemen usaha, serta konseling individu dan kelompok, khususnya yang terkait dengan masalah produksi dan pemasaran.

\section{SIMPULAN}

Kebijakan pemerintah tidak memberikan pengaruh terhadap praktik CSR oleh BSP Unit Jambi karena belum mengatur secara spesifik, rinci, dan tegas praktik CSR yang dijalankan oleh perusahaan-perusahaan di Indonesia. Sebagai contoh, regulasi pemerintah belum secara tegas mengatur besaran dana CSR yang harus dikeluarkan oleh perusahaan. Sanksi-sanksi terhadap perusahaan yang melanggar CSR juga belum dijabarkan secara teknis.

Praktik CSR oleh BSP Unit Jambi lebih bersifat mandiri, yaitu dengan memperhatikan arahan kebijakan dari Kelompok Usaha Bakrie dan Kantor Pusat BSP di Jakarta. BSP Unit Jambi lebih dahulu menjalankan CSR sebelum lahirnya kebijakan pemerintah. Meskipun demikian, CSR yang dijalankan BSP Unit Jambi telah sesuai dengan peraturan yang terkait.

Rancangan CSR BSP Unit Jambi disusun dengan mengikuti kaidah-kaidah yang berlaku pada tataran global.Di samping itu, praktik CSR juga memperhatikan kondisi dan kearifan lokal masyarakat di sekitar perusahaan. Jenis-jenis kegiatan CSR yang dijalankan mendukung kebijakan pemerintah yang terkait dengan upaya perluasan kesempatan kerja, penanggulangan kemiskinan, dan pengurangan kesenjangan.

Program CSR yang dijalankan mencakup bidang pendidikan, ekonomi, kesehatan, keagamaan, kepemudaan, lingkungan, infrastruktur, dan tanggap bencana. Bidang ekonomi menjadi prioritas melalui Kemitraan Inti-Plasma dalam perkebunan kelapa sawit. Perusahaan bertindak selaku inti, sedangkan para petani menjadi plasma. Sebagai inti, BSP Unit Jambi telahmeningkatkan kemampuan petani plasma dalam mengelola kebun dan menangani kegiatan pascapanen. 
Berbagai Program CSR yang dirancang dapat berlangsung secara optimal apabila didukung oleh strategi yang tepat dan komitmen yang kuat. Salah satu indikatornyaadalah BSP Unit Jambi selalu menyediakan dana untuk mendukung kegiatan CSR sesuai dengan kebutuhan di lapangan. Dana yang disediakan selalu meningkat setiap tahun dan terserap dalam proporsi yang tinggi, bahkan melampui target. Kondisi krisis ekonomi global sekalipun, BSP dan unit-unit bisnisnya tetap konsisten menjalankan CSR. Indikator lainnya adalah keterlibatan pimpinan dan karyawan BSP dalam pelaksanaan agenda-agenda CSR.

Strategi CSR yang ditempuh difokuskan pada kemitraan inti plasma kelapa sawit. Petani plasma bergabung dalam wadah koperasi, sehingga pembinaan dapat dilakukan secara komprehensif. Semua sendi kehidupan disentuh oleh program CSR dan masyarakat dilibatkan secara aktif sejak perencanaan, pelaksanaan, maupun ketika monitoring dan evaluasi. Hal ini merupakan kekuatan dari Kemitraan Inti-Plasma.

Sebaliknya, masih ditemukan berbagai kelemahan dalam penerapan strategi CSR oleh BSP Unit Jambi. Kebijakan dan strategi CSR masih bersifat atas-bawah dan keterlibatan masyarakat belum memadai. Sebagian petani plasma memandang bahwa BSP Unit Jambi melaksanakan CSR dengan pilih kasih dan tidak merata. Intensitas kunjungan dan komunikasi di antara karyawan perusahaan dengan masyarakat masih kurang, sehingga banyak informasi dan kegiatan CSR belum terdistribusi dengan baik sesuai dengan kebutuhan masyarakat lokal.

Manfaat utama praktik CSR BSP Unit Jambi adalah peningkatan pendapatan yang signifikan. Selain itu, terjadi pula perluasan kesempatan kerja, peningkatan pendidikan dan kesehatan, perbaikan infrastruktur, terciptanya hubungan kekeluargaan, serta peningkatan hubungan kemitraan dengan masyarakat lokal.Masyarakat yang awalnya miskin, telah mengalami perbaikan pendapatan secara drastis.

Prasarana dan sarana pendidikan dan kesehatan selalu diperbaiki setiap tahun, termasuk pemberian beasiswa dan tunjangan kepada guru. Di samping itu, kegiatan masyarakat ditunjang oleh dana CSR, seperti kegiatan keagamaan dan kepemudaan. Infrastruktur transportasi juga tidak luput, sehingga mobilitas masyarakat dapat berlangsung dengan baik. Demikian pula dengan pengelolaan lingkungan hidup melalui penataan hutan konservasi dan pemanfaatan lahan-lahan kosong dengan berbagai tanaman produktif.

\section{DAFTAR PUSTAKA}

Ali, I. Rehman, K.U; Ali, S.I; Yousaf, J; \& Zia, M. 2010. "Corporate Social Responsibility Influences, Employee Commitment and Organizational Performance". African Journal of Business Management, Vol. 4, No. 12; 2.796-2.801.

Anonim, 2007, “Integritas adalah Prinsip dan Kebanggaan Kita". Harmoni, Edisi 2, Vol. I, April.

2007, "Barometer Kemitraan Plasma Ada di Jambi". Harmoni, Edisi 3, Vol. I, Juli.

2007, "Kepercayaan dan Reputasi Tidak Gratis, Kita Harus Respek". Harmoni, Edisi 3, Vol. I, Juli.

2009, "Perlu Kreatifitas untuk Menjalankan CSR". Harmoni, Edisi 10, Vol. III, April.

2009, "Geliat Kegiatan CSR di BSP Unit Jambi". Harmoni, Edisi 11, Vol. III, Juli.

2010, "Geliat CSR Agrowiyana". Harmoni, Edisi 16, Vol. V, Oktober.

2011, "BSP Harus Punya Leadership yang Kuat". Harmoni, Edisi 17, Vol. $\mathrm{V}$, Januari.

2012. "PT. Bakrie Sumatera Plantations, Tbk.: Duit Mengalir Dari Produk Hilir". Info Sawit: Indonesian Palm Oil Magazine, Vol. VI, No. 7, Juli, hal. 22-23. 
Arifin, S, 2012,Hukum Perlindungan dan Pengelolaan Lingkungan Hidup di Indonesia. Jakarta: PT Sofmedia.

Aruman, 2012, "Indikatornya adalah Perubahan Positif". MIX Marketing Communications, 09/IX/September, hal. 78-79.

Aruman, 2012, “Integrated CSR Communications". MIX Marketing Communications, 09/IX/September, hal. 35-37.

Babbie, E, 2004, The Practice of Social Research, Tenth Edition. Belmont: Wadsworth.

Badan Pusat Statistik, 2007, Data dan Informasi Kemiskinan 2005-2006, Buku 2: Kabupaten. Jakarta.

2009, Data dan Informasi Kemiskinan 2008, Buku 2: Kabupaten/Kota. Jakarta.

2007, Indeks Pembangunan Manusia 2005-2006. Jakarta.

2009, Indeks Pembangunan Manusia 2007-2008. Jakarta.

2011, Tanjung Jabung Barat dalam Angka 2011. Tanjung Jabung Barat.

Baker, A. H, 2005, "Should UK Banks Be Subject to Corporate Social Responsibility Legislation?". Business Law Review, July, hal. 171-174.

Bansal, T, 2006, "Best Practices in Corporate Social Responsibility". Ivey Business Journal, March/April, hal. 1-3.

Baye, Michael R., 2006,Managerial Economics and Business Strategy. New York: The McGraw-Hill Companies, Inc.

Bovaird, T., \&Loffler, E, 2003,Public Management and Goverance. London: Routledge.

Brammer, S., Millington, A., \& Rayton, B, 2005, "The Contribution of Corporate Social Responsibility to Organizational Commitment". University of Bath School of Management: Working Paper Series.

Bustami, Reevany, 2012,Proceeding The $2^{\text {nd }}$ $I C B B$ and CSR-UN Conference, Kuta, Bali, 2-3 February.
Carroll, A. B, 1979, "A Three-Dimensional Conceptual Model of Corporate Performance". The Academy of Management Review, Vol. 4, hal. 497505.

Crowther, D., \& Aras, G, 2008,Corporate Social Responsibility. David Crowther, Guler Aras \& Ventus Publishing ApS.

Dye, T. R, 1981, Understanding Public Policy, Fourth Edition. New Jersey: Prentice Hall, Inc.

Egels, N, 2005, "CSR in Electrification of Rural Africa: The Case of ABB in Tanzania". Journal of Corporate Citizenship, No. 18, Summer, hal. 75-85.

Heal, G. 2005. "Corporate Social Responsibility: An Economic and Financial Framework." The Geneva Papers, No. 30, hal. 387-409.

Hilman, A.J. \& Keim, G.D, 2001. "Shareholder Value, Stakeholder Management, and Social Issues: What's The Bottom Line?" Strategic Management Journal, Vol. 22, hal. 125-139.

McWilliams, A; \& Siegel, D. 2000. “Corporate Social Responsibility and Financial Performance: Correlation or Misspecification?" Strategic Managment Journal, Vol. 21, Issue 5, hal. 603-609.

Morimoto, R; Ash, J; \& Hope, C. 2004. "Corporate Social Responsibility Audit: From Theory to Practice." Research Papers in Management Studies, WP 14.

Nurn, C. W; \& Tan, G. 2010. “Obtaining Intangible and Tangible Benefits from Corporate Social Responsibility." International Review of Business Research Papers, Vol. 6, No. 4, hal. 360-371.

Preston, L.E; \& O’Bannon, D.P. 1997. “The Corporate Social-Financial Performance Relationship: A Typology and Analysis". Business \& Society. Vol. 36, hal. 419-429. 
PT. Bakrie Sumatera Plantations Tbk. 2011. Laporan Kegiatan Tanggung Jawab Sosial 2010. Jakarta.

2010. Laporan Tahunan 2009. Jakarta. 2011. Laporan Tahunan 2010. Jakarta. Quevedo-Puente, E.D; Fuente-Sabaté, J.M. D.L; \& Delgado-García, J.B 2007. “Corporate Social Performance and Corporate Reputation: Two Interwoven Perspectives." Corporate Reputation Review, Vol. 10, No. 1, hal. 60-72.
Swa, Desember. 2005. Corporate Social Responsibility.

Ven, B.V.D; \& Jeurissen, R. 2005. “Competing Responsibly." Business Ethics Quarterly, Vol. 15, Issue 2, hal. 299-317.

Wood, D.J; \& Jones, R.E. 1995 “Stakeholder Mismatching: A Theoretical Problem in Empirical Research on Corporate Social Performance." International Journal of Organizational Analysis, Vol. 3, Issue 3, hal. 229 - 267. 